\title{
STRATEGI PEMASARAN WEDDING PACKAGES PADA MY WEDDING ORGANIZER
}

\author{
Ni Nyoman Wulan Antari ${ }^{1}$ \\ Riza Wulandari \\ ITB STIKOM Bali, Indonesia ${ }^{1,2}$ \\ email: wulanantari03@gmail.com
}

\begin{abstract}
In developing a business in the field of marriage, My Wedding Organizer has designed several wedding packages for brides who want a party that is only attended by a few people (privacy). By working with several reception venues and several other wedding organizers, My wedding organizer has succeeded in making customers feel satisfied with the wedding packages offered. However, in 2019 My Wedding Organizer was not able to achieve the expected target, thus we conducted research aimed at increasing sales of wedding packages on My Wedding Organizer by making a strategy formulation by analyzing the marketing mix of $7 P$ services consisting of products and services, prices, channels. I place of distribution, promotion, people, facilities (physical evidence) and processes based on a SWOT analysis. Based on the research of this study in increase of sales of wedding packages which decreased especially in 2019, namely the creation of a new strategy formulation is based on the SWOT analysis 7P. The conclusions of the study are based on the marketing mix by creating a SWOT matrix, from strategy $S O, W O, S T$ and WT in strategy formulation it can be based on the $7 P$ include product, price, distribution channels / place, promotion, people, processes, and the physical evidence. It is recommended to use the hotel management corporate strategy formulation and business unit strategy formulation, with the wedding venue evaluate and innovate to create a new wedding packages to explore creativity in the promotional aspect of wedding.
\end{abstract}

Keywords: $\quad$ wedding packages, marketing mix, marketing strategy.

\section{PENDAHULUAN}

Bali merupakan salah satu pulau yang paling dicari sebagai tujuan berlibur bagi setiap orang di belahan dunia manapun. Pulau kecil nan menawan ini memberikan kesan tersendiri bagi mereka yang berlibur. Selain terkenal dengan pantai dan pura, kebudayaan yang cukup beragam disetiap daerah serta penduduk setempat yang begitu ramah membuat wisatawan enggan untuk segera pergi dari pulau ini.

Selain berlibur, Bali juga menjadi salah satu diantara sepuluh destinasi pernikahan yang paling diminati orang dari seluruh dunia. Selain karena keindahan alam dan dikenal dengan pulau seribu pura, Bali juga memiliki banyak akomodasi dan calon mempelai dapat meggabungkan budaya Bali dengan budaya luar pada pernikahan mereka. Tidak hanya itu, Bali sanggup melayani surat (dokumen) pernikahan dengan sangat baik. Menurut (Abraham, 2011;01) dalam http://www.uniknya.com pulau Bali dinobatkan sebagai salah satu antatra lima tempat terbaik dalam 
melangsungkan pernikahan. Hal tersebut dibuktikan dengan tercatat banyaknya wisatawan yang menikah dan melakukan bulan madu di pulau Bali. Menurut mereka pulau Bali memiliki daya Tarik tersendiri yang begitu eksotis, baik pantai, pemandangan, maupun budaya yang ada di dalamnya.

Sebagai salah satu wedding organizer yang berada di Bali, My Wedding Organizer sangat diminati wisatawan yang menginginkan pernikan yang sederhana dan cenderung ditutup untuk keluarga dekat. Karena My Wedding Organizer mengkhususkan pemasarannya untuk pernikahan yang tertutup, terjadi kesenjangan Antara permintaan dan penyelenggaraan pernikahan yang diorganisir oleh My Wedding Organizer ini seperti yang terlihat pada table permintaan dan pelaksanaan pernikahan perbulannya pada tahun 2019.

$\begin{array}{cc}\text { Perbandingan } & \text { jumlah } \\ \text { permintaan terhadap jumlah }\end{array}$
penyelenggaraan pada My Wedding Organizer.

Tabel 1

Tahun 2019

\begin{tabular}{cccc}
\hline BULAN & $\begin{array}{c}\text { Jumlah } \\
\text { booking }\end{array}$ & $\begin{array}{c}\text { Penyelenggaran } \\
\text { pernikahan }\end{array}$ & $\begin{array}{c}\text { Persentase } \\
\text { perbandingan } \\
(\%)\end{array}$ \\
\hline Januari & 16 & 4 & 25.00 \\
Februari & 20 & 4 & 20.00 \\
Maret & 15 & 2 & 13.33 \\
April & 24 & 3 & 12.50 \\
Mei & 20 & 5 & 25.00 \\
Juni & 26 & 3 & 11.54 \\
Juli & $\mathbf{4 0}$ & $\mathbf{2}$ & $\mathbf{5 . 0 0}$ \\
Agustus & 33 & 3 & 9.09 \\
September & 24 & 3 & 12.50 \\
Oktober & 18 & 4 & 22.22 \\
November & 21 & 3 & 14.29 \\
Desember & 30 & 0 & 0.00 \\
\hline Jumlah & $\mathbf{2 8 7}$ & $\mathbf{3 6}$ & $\mathbf{1 2 . 5 4}$ \\
\hline
\end{tabular}

Sumber: My Wedding Organizer (data diolah)

\begin{abstract}
Dari table 1 dapat dilihat bahwa jumlah booking tidak sebanding dengan penyelenggaraan pernikahan. Pada bulan januari terdapat 16 bookingan pernikahan yang tercatat namun hanya 4 bookingan yang terselenggara. Pada bulan juli terjadi lonjakan pemesanan yakni terdapat 40 pasangan yang ingin pernikahan mereka digarap oleh My Wedding Organizer, namun setelah melakukan obrolan secara intensif, hanya 2 pasangan yang menyelenggarakan pernikahan dengan
\end{abstract}

bantuan organizer ini. Bahkan pada bulan desember terdapat 30 bookingan yang tercatat, namun tidak satupun bookingan tersebut dapat terselenggara karena virus corona mulai merambah dunia pariwisata dunia sehingga customer memutuskan untuk membatalkan bookingan mereka terhadap My Wedding Organizer.

Menjalin suatu kerja sama antara My Wedding Organizer dengan beberapa pihak terkait seperti tempat penyelenggaraan dan beberapa agen 
terkait sangat dibutuhkan untk mempromosikan paket pernikahan agar My Wedding Organizer lebih dikenal. Disamping itu media social juga belum begitu dikenal masyarakat, sehingga pernikahan yang diselenggarakan belum mencapai target maksimal.

Hal ini merupakan salah satu alasan mengapa harus ada penelitian untuk menentukan langkah dan strategi pemasaran yang diperlukan pada pelaksanaan pernikahan, mengingat begitu banyaknya pesaing, sehingga My Wedding Organizer mampu meningkatkan pelayanan dan jumlah pernikahan secara maksimal.

\section{Rumusan Masalah}

Berdasarkan latar belakang diatas, makan dapat dirumuskan permasalahan dalam penelitian ini yakni "Bagaimana strategi pemasaran wedding packages yang tepat untuk diterapkan oleh My Wedding Organizer?

\section{Tujuan Penelitian}

Penelitian ini bertujuan untuk mengetahui strategi pemasaran (paket pernikahan) yang tepat untuk diterapkan oleh My Wedding Organizer, serta memberikan alternatif strategi pemasaran wedding packages yang tepat untuk diterapkan oleh My Wedding Organizer.

\section{Batasan Masalah}

Ruang lingkup permasalahan ini hanya berbatas pada strategi pemasaran wedding packages yang tepat untuk diterapkan melalui penyelenggaraan pernikahan dengan menganalisa strategi pemasaran dengan meneliti pada kegiatan pemasaran yakni 7P antara lain tempat (place), produk/jasa (Product), orang (people), promosi (promotion), harga (price), proses (process), dan fisik (physical evident) pada My wedding organizer.

\section{TINJAUAN PUSTAKA Kajian Pustaka}

Terdapat beberapa penelitian terdahulu yang penulis jadikan referensi untuk pembuatan penelitian ini. Salah satunya adalah penelitian yang dibuat oleh $\mathrm{Ni}$ Luh Putu Widyawati yang berjudul "Strategi Pemasaran Wedding Packages di Four Season Bali at Jimbaran Bay". Teknik pengumpulan data yang beliau gunakan dalam penelitian ini dengan menyebarkan kuisioner pada tamu yang pernah menyelenggarakan Wedding di Four Season Bali at Jimbaran Bay, dimana hasil yang didapatkan adalah terdapat beberapa hal yang harus menjadi perhatian pihak manajemen agar dapat bersaing dengan kompetitor serta meningkatkan penjualan wedding packages antara lain wedding venue, sub aspek, kemudian akses mendapatkan informasi melalui travel agent atau wedding agent, aspek promosi (promotion) yang nilai yang kurang, dan aspek physical evidence. Sedangkan dari aspek harga (price), orang (people), dan proses (process) sudah mendapat penilaian yang sangat baik dari para tamu yang menyelenggarakan wedding di Four Season Bali at Jimbaran Bay.

Dari penilaian tersebut terdapat beberapa perbedaan antara penelitian terdahulu dengan penelitian ini yakni dengan judul "Strategi Pemasaran Wedding Packages di My Wedding Organizer". Dimana terdapat tujuan dari penelitian ini ialah untuk mengetahui strategi yang tepat dalam meningkatkan penjualan wedding package di My Wedding Organizer. Sesuatu yang membuat penelitian ini 
berbeda dengan penelitian sebelumnya yakni terletak pada rumusan masalah, teknil analisis data dan pengumpulan data. Adapun rumusan masalah dalam penelitian ini adalah Bagaimana strategi pemasaran wedding packages yang tepat untuk diterapkan oleh My Wedding Organizer, serta analisis data, peneliti memilih untuk menggunakan teknik analisis SWOT. Teknik pengumpulan data yang peneliti gunakan yaitu dokumentasi dan wawancara.

\section{Landasan Teori}

\section{Strategi Pemasaran}

Andrews (Alma, 2000:157) berpendapat bahwa strategi merupakan sebuah keputusan dalam perusahaan yang menentukan dan mengungkapkan sasaran, maksud dan tujuan yang menghasilkan kebijaksanaan utama dan merencanakan untuk pencapaian tujuan serta merinci jangkauan bisnis yang akan dikejar perusahaan.
Setiap perusahaan mempunyai tujuan untuk dapat tetap hidup dan berkembang, tujuan tersebut hanya dapat dicapai melalui usaha mempertahankan dan meningkatkan tingkat keuntungan/laba perusahaan. Usaha ini hanya dapat dilakukan, apabila perusahaan dapat mempertahankan dan meningkatkan penjualannya, melalui usaha mencari dan membina langganan, serta usaha menguasai pasar. Tujuan ini dapat dicapai, apabila bagian pemasaran perusahaan melakukan strategi yang mantap untuk dapat menggunakan kesempatan dan peluang yang ada asaran, sehingga posisi atau kedudukan perusahaan di pasar dapat dipertahankan bahkan ditingkatkan.

Analisis SWOT

Analisis SWOT merupakan identifikasi sebagai factor secara sistematis untuk merumuskan hal sebagai berikut:

Tabel 2

Analisis SWOT

\begin{tabular}{|c|c|c|}
\hline \multirow{2}{*}{ EFAS } & Kekuatan strength (s) & $\begin{array}{l}\text { Kelemahan weaknesses } \\
\text { (w) }\end{array}$ \\
\hline & Factor kekuatan internal & $\begin{array}{l}\text { Faktor } \\
\text { internal }\end{array}$ \\
\hline \multirow{2}{*}{$\begin{array}{l}\text { Peluang opportunities } \\
\text { (o) }\end{array}$} & Strategi SO & \\
\hline & 1 & 3 \\
\hline $\begin{array}{l}\text { Factor } \\
\text { eksternal }\end{array}$ & $\begin{array}{l}\text { Menciptakan strategi yg } \\
\text { menggunakan kekuatan yg } \\
\text { dimiliki untuk } \\
\text { memanfaatkan peluang }\end{array}$ & $\begin{array}{l}\text { menciptakan strategi yg } \\
\text { meminimalkan untuk } \\
\text { memanfaatkan peluang }\end{array}$ \\
\hline \multirow[t]{2}{*}{ Ancaman threat $(\mathrm{t})$} & Strategi ST & \multirow{3}{*}{$\begin{array}{l}\text { Strategi WT } \\
4 \\
\text { menciptakan strategi yg } \\
\text { meminimalkan } \\
\text { kelemahan dan } \\
\text { menghindari ancaman }\end{array}$} \\
\hline & 2 & \\
\hline $\begin{array}{l}\text { Factor } \\
\text { eksternal }\end{array}$ & $\begin{array}{l}\text { Menciptakan strategi dgn } \\
\text { menggunakan kekuatan } \\
\text { untk mengatasi ancaman }\end{array}$ & \\
\hline
\end{tabular}

Sumber: Rangkuti (2004)

\section{Bauran Pemasaran}

Zeithaml dan Bitner

(2000:19) menyatakan pemasaran jasa perlu bauran pemasaran yang diperluas (expanded marketing mix for service) dengan penambahan unsur non-traditional marketing mix sehingga terdiri dari 7P yaitu product, price, place, promotion, people, physical, evidence and process. 
Penambahan strategi perusahaan. Analisa ini didasarkan pada hubungan atau interaksi antara beberapa undur internal yakni kekuatan (strength), dan kelemahan (weakness) terhadap unsur eksternal yakni peluang(opportunity) serta ancaman (threat).

\section{Strategi Pemasaran}

Strategi

pemasaran

didefinisikan sebagai kegiatan yang direncanakan dan diorganisasikan yang meliputi distribusi produk, penetapan harga dan melakukan pengawasan terhadap kebijakan kebijakan yang tealh dibuat yang tujuannya untuk mendapatkan tempat dipasaran serta tujuan utama pemasaran tercapai dengan baik.

\section{Pernikahan (Wedding)}

Daniels dan Loveless menyebutkan dalam buku yang mereka buat yang berjudul Wedding Planning and Management (2007:213): "the meaning of marriage ultimately comes back to the moment when two individuals publicly pledge their commitment to one another." (Makna dari pernikahan pada akhirnya kembali pada momen ketika dua individu secara terbuka menyatakan komitmen mereka satu sama lain.).

\section{Wedding Packages}

Wedding packages (paket Pernikahan) adalah paket pernikahan yang dikemas sedemikian rupa yang diupayakan semenarik mungkin agar pasangan calon pengantin yang ingin melangsungkan pernikahan merasa tertarik dengan rangkaian paket yang ditawarkan dan bersedia membeli paket ini.

\section{METODE PENELITIAN}

\section{Objek Penelitian}

Penelitian ini dilakukan pada

My Wedding Organizer yang berdiri sejak tahun 2006. Dengan objek penelitian pada Strategi Pemasaran Wedding Packages pada My Wedding Organizer.

Penelitian ini dilaksanakan dari bulan Maret 2020 hingga September 2020. Diharapkan selama 6 bulan, penelitian ini sudah dapat diselesaikan.

\section{Jenis Penelitian}

Jenis penelitian yang dipakai adalah penelitian deskriptif, yakni mendeskripsikan atau menerangkan data yang telah terkumpul secara logis yang disertai dengan argumentasi agar dapat menarik kesimpulan.

\section{Jenis dan Sumber Data}

\section{Jenis Data}

Data yang penulis pakai dalam penelitian ini adalah data kuantitatif dan kualitatif dimana data kuantitatif tersebut berupa jumlah permintaan dan jumlah pelaksanaan pernikahan selama tahun 2019. Data kualitatif berupa data paket pernikahan yang ditawarkan serta strategi pemasaran yang dilakukan yang dilakukan My Wedding Organizer.

\section{Sumber Data}

Sumber data dalam penelitian ini antara lain hasil wawancara dengan pemilik My Wedding Organizer. Sedangkan data sekunder merupakan data yang disediakan dan diolah oleh pihak sumber data seperti paket pernikahan 2019 serta beberapa kontrak degan beberapa tempat pernikahan.

\section{Teknik Pengumpulan Data}

Wawancara yang dilakukan dalam penelitian ini berupa Tanya jawab langsung dengan pemilik My Wedding Organizer untuk memperoleh beberapa informasi yang dibutuhkan dalam penelitian ini, seperti informasi proses penjualan paket pernikahan yang didapatkan dari pemilik My Wedding Organizer. Selain itu, pengumpulan data berupa 
catatan serta dokumen pelaksanaan pernikahan yang dilaksanakan oleh My Wedding Organizer.

\section{Teknik Analisis Data}

SWOT merupakan suatu analisis yang dapat dipergunakan untuk merumuskan strategi pemasaran yang terdiri atas kekuatan, kelemahan, peluang, dan ancaman yang dihadapai oleh perusahaan untuk mencapai tujuan. Rangkuti (2006:18) menyatakan bahwa, untuk merumuskan strategi berdasarkan pada logika yang dapat memaksimalkan kelemahan dan ancaman. Selanjutnya akan dilakukan alternative strategi berupa matriks SWOT yang menghasilkan empat strategi, antara lain:
a. Strategi SO (Strengths- Opportunities) yaitu memanfaatkan seluruh kekuatan untuk memanfaatkan peluang.
b. Strategi ST (Strengths- Threat) yaitu strategi dalam menggunakan

kekuatan yang dimiliki mengatasi ancaman yang timbul.

c. Strategi WO (Weaknesses Opportunities) yakni strategi meminimalkan kelemahan yang ada dengan memanfaatkan peluang yang ada.

d. Strategi WT (Weaknesses Threat) yaitu strategi untuk meminimalkan kelemahan yang dimiliki seerta menghindari ancaman yang mungkin hadir.

Keempat strategi tersebut dapat dilihat dalam table dibawah. Table tersebut menerangkan bagaimana cara untuk mengembangkan strategi dengan alat bantu matriks SWOT yang dapat menggambarkan bagaimana peluang dan ancaman eksternal yang dihadapi perusahaan / organisasi yang selanjutnya desesuaikan dengan kekuatan serta kelemahan internal yang dimiliki.

Tabel 3

Matriks SWOT

IFAS Kekuatan strength (s) Kelemahan weaknesses (w)

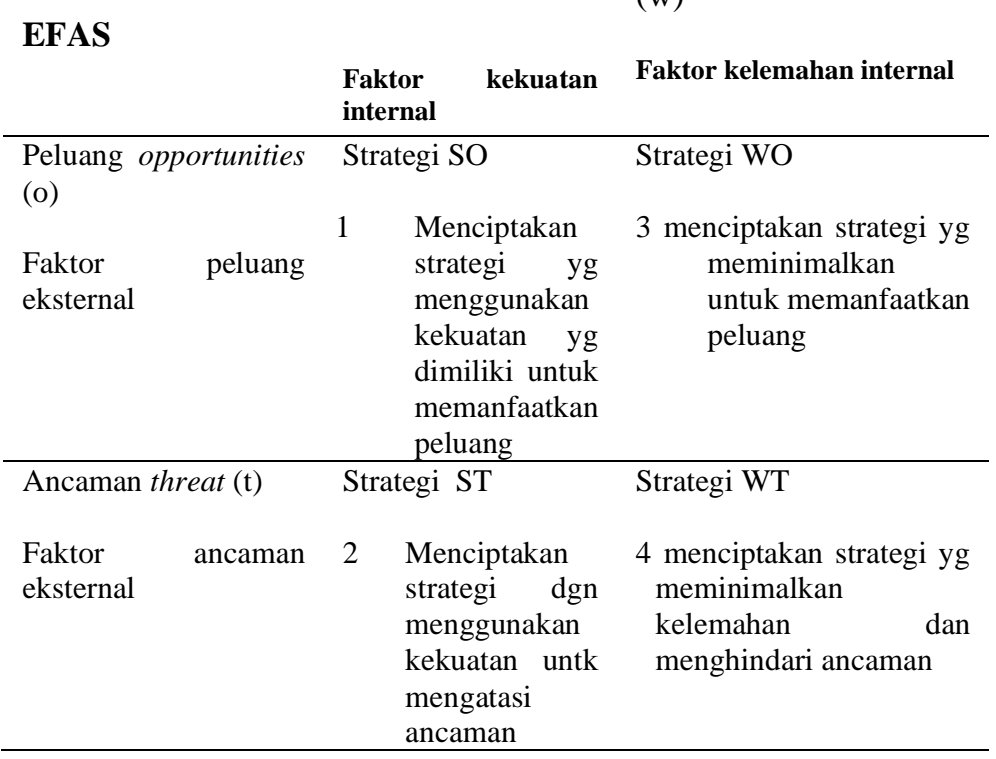




\section{HASIL DAN PEMBAHASAN \\ Hasil Wawancara}

Peneliti telah melakukan wawancaran kepada pemilik My Wedding Organizer, berdasarkan $7 \mathrm{P}$ yaitu produk (product), harga (Price), saluran distribusi/tempat (place), promosi (promotion), orang (people) proses (process), dan bukti fisik (physical evidence) menentukan strategi yang tepat untuk peningkatan penjualan paket pernikahan di My Wedding Organizer.

Berdasarkan hasil wawancara yang didasari $7 \mathrm{P}$ antara lain produk (product), harga (price), saluran distribusi/tempat (place), promosi (promotion), orang (people), proses (process), dan ukti fisik (physical evidence) dapat disimpulkan bahwa My Wedding Organizer memiliki 4 tempat yang kami pakai untuk area resepsi, 1 tempat mempunyai area indoor dan outdoor, 1 area yang hanya menyediakan pelayanan outdoor dan 2 area hanya mempunyai gedung resepsi saja (indoor). Untuk harga paket yang ditawarkan, My Wedding Organizer melakukan observasi pada beberapa instansi yang menjadi pesaing kami sebelum menetapkan harga. Hal ini dilakukan agar harga tetap stabil dan tidak jauh berbeda dengan pelaku bisnis serupa lainnya. Selain itu kami juga terus memantau harga yang ditawarkan tempat resepsi yang dapat diajak kerja sama. My Wedding Organizer menyediakan dan menawarkan 3 paket yang mana sesuai konsep awal kami yaitu private party. Paket tersebut antara lain Ubudo package (maksimal 25 orang), Benoa Package (maksimal 35 orang), dan Tabanan Package (maksimal 65 orang). Yang mana paket pernikahan yang paling dicari selama ini adalah Benoa Package, yang mana menurut mereka paket ini berhasil memberikan kesan akrab bagi pasangan pegantin, keluarga dan tamu yang hadir. My Wedding Organizer membutuhkan waktu 1-2 bulan untuk memproses hingga merampungkan pelaksanaan pernikahan. Waktu yang terlama mereka habiskan untuk menyamakan persepsi dengan customer. Karena kami ingin customer kami benar benar puas terhadap service yang diberikan. Dalam menjalankan tugas, My Wedding Organizer melakukan kerja sama dengan 2 wedding organizer lain, yakni Els Bridal dan Tirta Bridal. Tujuannya adalah jika My Wedding Organizer tidak sanggup menjalankan permintaan pernikahan karena berbagai alasan, kami akan menawarkan pada kedua organizer tersebut. Begitu juga dengan mereka, jika ada hal serupa, mereka juga melakukan hal yang sama. Dalam melakukan pemasaran, tentunya terdapat promosi yang harus dilakukan agar organisasi dapat dikenal masyarakan luas. Beberapa jenis promosi pernah dijajaki dari awal hingga saat ini, antara lain menyebarkan brosur, promosi melalui radio, dan pemasaran melalui mulut ke mulut. Kendala terberat yang dialami pemilik adalah sebuah kecenderungan kekurangan SDM yang membantu saya dalam menyelesaikan kegiatan. Kami sering melakukan pekerjaan merangkap karena jumlah personil kami tidak sebanyak wedding organizer lainnya. Maka dari itu, hal yang dapat dilakukan antara lain adalah salin membantu pekerjaan rekan, kami berusaha melakukan pekerjaan secara estapet, ya istilahnya kerja serabutan agar mempercepat penyelesaian dan meminimalisir kesalahan. Setelah acara selesai, kami selalu melakukan rapat evaluasi agar 
perkara saat ini diupayakan agar tidak terjadi pada acara berikutnya.

\section{Analisis SWOT}

Berdasarkan fakta yang didapat dari My Wedding Organizer dari rangkuman guest comment dan pemilik dapat dikembangkan suatu alternative strategi yang dilakukan melalui analisis SWOT yang didasarkan pada situasi lingkungan internal dan eksternal. Berikut ini adalah paparan analisis SWOT tentang pemasaran paket pernikahan:

\section{Kekuatan (Strenghts)}

Berikut ini adalah faktor-faktor kekuatan yang dapat di identifikasi, antara lain:

a. Memiliki beberapa pilihan paket pernikahan dengan berbagai macam kapasitas dan view dengan salah satunya ruangan luas yang membuat parapengunjung merasa nyaman dalam berkomunikasi.

b. Lokasi resepsi strategis untuk menyelenggarakan pernikahan sehingga mudah ditemui oleh tamu undangan.

c. Penataan yang unik membuat customer merasa betah dan nyaman selama mengikuti acara.

d. Area parkir yang cukup luas membuat customer mudah memarkirkan kendaan mereka.

\section{Kelemahan (weaknesses)}

Adapun beberapa factor yang menjadi kelemahan yang dapat diidentifikasi, antara lain:

a. Promosi yang dilakukan masih manual sehingga gaungnya belum terlalu dikenal masyarakat secara luas. b. Harga paket pernikahan yang tidak sesuai dengan paket yang ditawarkan membuat customer membatalkan pesanan mereka.

c. Jumlah pengunjung tidak sebanding dengan besar gedung yang lebih besar membuat kesan yang kurang menarik bagi customer.

d. Kurangnya SDM saat penyelenggaraan pernikahan mempengaruhi pelayanan terhadap pelanggan. Keterbatasan staff saat penyelenggaraan membuat pelayanan berkurang.

\section{Peluang (opportunities)}

Berikut adalah faktor peluang yang dapat dijabarkan.

a. dizaman sibuk seperti ini customer ingin melakukan segala sesuatu yang jauh lebih praktis dan simple. Customer cenderung menuntut apapun yang mereka inginkan tersedia tanpa harus menghabiskan banyak tenaga.

b. Tersedianya berbagai objek wisata dan penginapan dapat ditawarkan sebagai penggandeng paket yang telah ada sebagai daya tarik customer.

c. Kedatangan wisatawan baik domestik maupun mancanegara ke pulau Bali, tidak hanya membawa daya tarik terhadap panorama dan kebudayaan namun juga membawa dampak positif untuk mempromosikan paket pernikahan yang dimiliki kepada wisatawan.

d. Perubahan trend pasar dalam menawarkan dan menjual paket pernikahan seiring 
dengan perkembangan zaman, factor ekonomi yang berubah ubah yang dibarengi dengan kemajuan teknologi yang begitu pesat membuat trend pasarpun berubah yang disesuaikan dengan minat dari customer. Hal ini sangat membantu penjualan paket pernikahan bagi wisatawan mancanegara.

\section{Ancaman (Threats)}

Terdapat beberapa faktor yang menjadi ancaman yang menjadi ancaman, antara lain:

a. Semakin banyaknya pesaing dari beberapa pihak terutama semakin banyak hotel yang menyediakan fasilitas wedding organizer yang membuat customer lebih memilih menyelenggarakan pernikahannya include dengan penginapan yang membuat pengeluarannya menjadi lebih sedikit.

b. Bencana alam dan wabah penyakit yang datang tanpa terduga tidaklah dapat dihindari namun masih dapat ditanggulangi dengan melakukan persiapan yang tepat. Sebagai contoh saat ini wabah covid 19 masih merajalela. Sebagai sebuah komunitas menyedia jasa, My Wedding Organizer menyediakan beberapa alat untuk melindungi diri dalam proses hingga pelaksanaan acara seperti masker, face shield, alat dan bahan cuci tangan dan hand sanitizer kepada staff dan customer.

c. Rentan terjadinya beberapa interaksi menyimpang secara terselubung saat acara berlangsung, seperti pesta miras, transaksi narkoba, menjadikan salaha satu pengunjung sebagai target karena dendam pribadi, ancaman bom dan kejadian lainnya yang membahayakan semua pihak. Maka dari itu sangat diperlukan pengawasan dari semua pihak untuk menghindari hal seperti ini terjadi agar prosesi pelaksanaan pernikahan berjalan dengan kondusif.

\section{Strategi alternatif}

Setelah melakukan analisis SWOT, terdapat beberapa langkah berikutnya yang dipakai dalam proses perencanaan untuk mencapai tujuan yang dipilih. Analisis SWOT dapat diterapkan dengan cara menganalisis dan memilah berbagai berbagai hal yang mempengaruhi keempat faktornya, lalu menerapkannya dalam gambar matriks SWOT, dari hasil analisis ini dapat dilihat bagaimana kekuatan (strengths) mengambil beberapa keuntungan (adventage) dari peluang yang ada (Opportunities) hal ini dapat disebut dengan "strategi WO", selanjutnya dapat diamati bagaimana cara kekuatan (strength) mampu menghadapi berbagai ancama (threats) ang menghadang, kemampuan ini dapat disebut dengan "Strategi ST". Hal terakhir yang dapat diamati adalah bagaimana cara mengatasi kelemahan (weaknesses) yang sanggp membuat ancaman (threats) menyadi nyata, hal ini dikenal dengan "Strategi WT".semua straegi ini dapat dilakukan dengan alat bantu matriks SWOT.

EFAS merupakan analisis faktor strategi eksternal yang difokuskan pada kondisi yang ada serta kemunculannya memiliki 
Journal of Applied Management and Accounting Science ( J A M A S )

(Ni Nyoman Wulan Antari, Riza Wulandari 23 - 40)

Vol 2, No 1, Desember 2020

kecenderungan dari luar organisasi, namun hal ini berpengaruh bagi kinerja organisasi setelah anggota organisasi mengetahui faktir dari strategi eksternal. Sedangkan IFAS merupakan merupakan faktor strategi internal, dimana factor ini menilai kinerja yang merupakan faktor kelemahan maupun kekuatan yang dimiliki organisasi.
Setelah melakukan penjabaran dari beberapa factor dari analisis SWOT yang terdiri atas kekuatan (strength), kelemahanan (weaknesses), peluang (opportunities), dan ancaman (threats) maka dapat dibuatkan strategi alternatif seperti yang tergampar pada table berikut ini

Tabel 4

Matrik SWOT

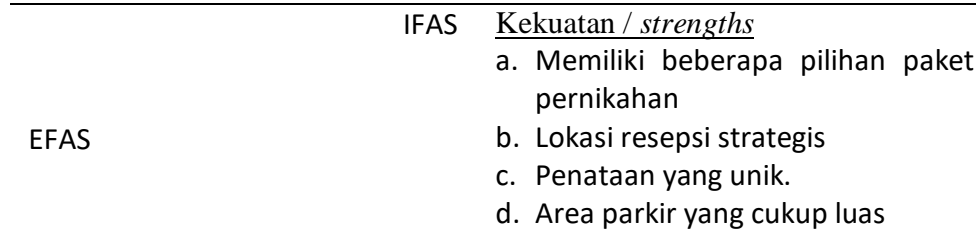

Kelemahan/weaknesses

a. Promosi yang dilakukan masih manual

b. Harga paket pernikahan yang tidak sesuai dengan paket yang ditawarkan

c.Jumlah pengunjung tidak sebanding dengan besar gedung yang lebih besar

d.Kurangnya SDM saat penyelenggaraan pernikahan mempengaruhi pelayanan terhadap pelanggan.

Peluang/opportunities

a.Customer ingin praktis

b.Tersedianya berbagai wisata dan penginapan dapat ditawarkan

c.Kedatangan wisatawan baik domestik maupun mancanegara ke pulau Bali,

d.Perubahan trend pasar dalam menawarkan dan menjual paket pernikahan

\section{$\underline{\text { Strategi SO }}$}

1. Berinovasi menciptakan produk packages baru seperti anniversary packages

2. Dengan menganalisa trend pasar yang berkembang saat ini untuk penjualan paket pernikahan.

3. Memperbaharui

informasi untuk customer dengan memperbaharui website, dan sering mengupload di sosal media dan media cetak.

4. Memanfaatkan lokasi yang strategis dalam mempromosikan paket pernikahan, seperti memanfaatkan Denpasar Festival

5. Lebih banyak menjalin kerja sama dengan penginapan (hotel, villa, dsb) agar memperbanyak ballroom untuk penyelenggaraan pernikahan.

\section{Strategi WO}

1. Promosi lebih digencarkan agar lebih dikenal dan mudah dicari oleh calon pasangan yang akan menikah, sehingga dapat memperbanyak wisatawan mancanegara yang ingin mengadakan acara pernikahan di Bali.

2. Tempat yang digunakan untuk megadakan acara pernikahan disesuaikan dengan jumlah pengunjung. alangkah lebih bijak dan menarik jika menentukan tempat didekat objek wisata yang sedang booming saat ini dengan mengusung tema garden party.

3. Menentukan dekorasi dan desigen sesuai dengan budget customer

4. Memperbaiki kualitas pelayanan dalam penyelenggaraan pernikahan agar dapat meminimalisir complain.

5. Menambah SDM saat penyelenggaraan pernikahan agar pekerjaan menjadi lebih mudah dan cepat diselesaikan.

6. Evaluasi kinerja harus dilakukan sesering mungkin agar mencapai kesepahaman dan sama sama berupaya untuk meminimalisir kesalahan yang telah terjadi kembali terjadi pada acara berikutnya.

Ancaman/threats
a. Semakin banyaknya pesaing
dari beberapa pihak
b. Bencana alam dan wabah
penyakit yang datang tanpa
terduga
c. Rentan terjadinya beberapa
interaksi menyimpang secara
terselubung saat acara
berlangsung.

Strategi ST

1. Mengnambah paket pernikahan yang lebih menarik untuk periode tertentu dan mengkombinasikan produk lama dengan paket tambahan seperti menyewakan kamar di salah satu hotel, dan spa tanpa mengubah makna dari paket tersebut

2. Merehabilitasi lokasi pernikahan seperti dekorasi dan design area agar terlihat jauh lebih fleksibel dan menarik dan tetap mampu bersaing

3. Tetap menjaga pesaing dengan mempertahankan produk lama di pasar yang baru.

\section{Strategi WT}

1. Meningkatkan keamanan dari saat pemesanan, proses, hingga acara berlangsung

2. Meminimalkan isu terror kepada customer agar mudah terpengaruh dan panic, sehingga tetap memesan paket pernikahan

3. Memperluas promosi dengan mengkuti pameran saat event event tahunan seperti Denpasar Festival dan memasang foto acara yang telah berlangsung. 
Dari tabel SWOT diatas, didapatkan strategi alternatif, diantaranya:

1. Dari Strategi SO (strength opportunities), yakni Berinovasi menciptakan produk packages baru seperti anniversary packages, Dengan menganalisa trend pasar yang berkembang saat ini untuk penjualan paket pernikahan. Memperbaharui informasi untuk customer dengan memperbaharui website, dan sering mengupload di sosal media dan media cetak. Memanfaatkan lokasi yang strategis dalam mempromosikan paket pernikahan, seperti memanfaatkan Denpasar Festival, Lebih banyak menjalin kerja sama dengan penginapan (hotel, villa, $\mathrm{dsb}$ ) agar memperbanyak ballroom untuk penyelenggaraan pernikahan.

2. Dari Strategi ST (strength-threat) yaitu Mengnambah paket pernikahan yang lebih menarik untuk periode tertentu dan mengkombinasikan produk lama dengan paket tambahan seperti menyewakan kamar di salah satu hotel, dan spa tanpa mengubah makna dari paket tersebut; Merehabilitasi lokasi pernikahan seperti dekorasi dan design area agar terlihat jauh lebih fleksibel dan menarik dan tetap mampu bersaing; Tetap menjaga pesaing dengan mempertahankan produk lama di pasar yang baru.

3. Dari strategi WO (weaknesses opportunities) yakni Promosi lebih digencarkan agar lebih dikenal dan mudah dicari oleh calon pasangan yang akan menikah, sehingga dapat memperbanyak wisatawan mancanegara yang ingin mengadakan acara pernikahan di Bali; Tempat yang digunakan untuk megadakan acara pernikahan disesuaikan dengan jumlah pengunjung. alangkah lebih bijak dan menarik jika menentukan tempat didekat objek wisata yang sedang booming saat ini dengan mengusung tema garden party; Menentukan dekorasi dan desigen sesuai dengan budget customer; Memperbaiki kualitas pelayanan dalam penyelenggaraan pernikahan agar dapat meminimalisir complain; Menambah SDM saat penyelenggaraan pernikahan agar pekerjaan menjadi lebih mudah dan cepat diselesaikan; Evaluasi kinerja harus dilakukan sesering mungkin agar mencapai kesepahaman dan sama sama berupaya untuk meminimalisir kesalahan yang telah terjadi kembali terjadi pada acara berikutnya.

4. Dari strategi WT (weaknesses threats), yaitu Meningkatkan keamanan dari saat pemesanan, proses, hingga acara berlangsung; Meminimalkan isu terror kepada customer agar mudah terpengaruh dan panik, sehingga tetap memesan paket pernikahan; Memperluas promosi dengan mengkuti pameran saat event event tahunan seperti Denpasar Festival dan memasang foto acara yang telah berlangsung. 


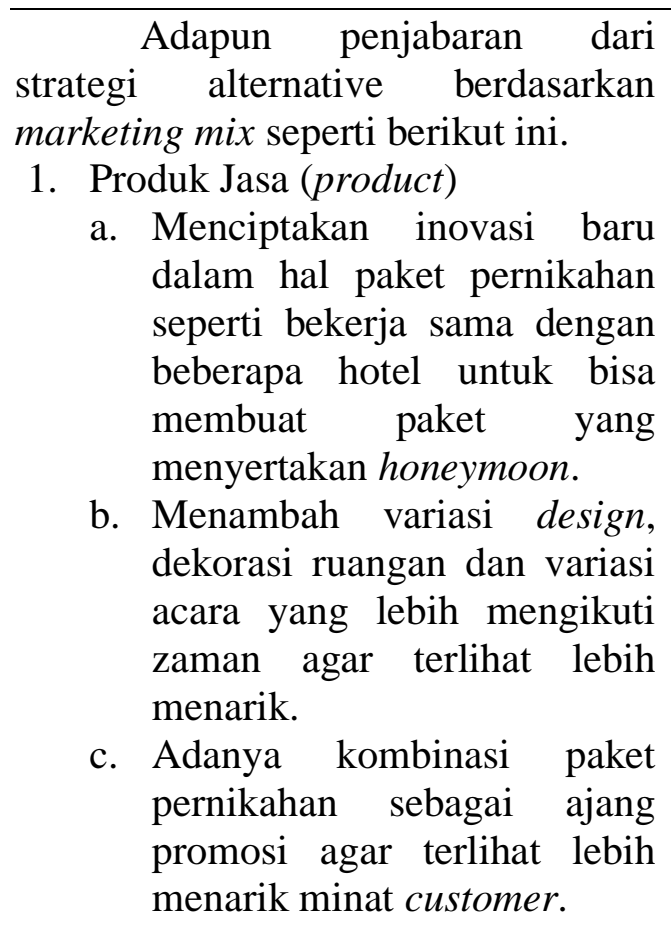

2. Harga (price)

a. Perlunya penetapkan harga yang sesuai dengan budget namun tetap dapat menyesuaikan dengan program yang diinginkan customer.

b. Membuat paket pernikahan dengan versi baru sesuai dengan perkembanga zaman, dengan harga yang mampu bersaing dengan competitor dalam penjualan produk.

c. Melakukan pencocokan, pembentukan, serta penyesuaian haga dalam mengarahkan customer saat memilih paket pernikahan yang sesuai dengan kebutuhan dan keinginan mereka, baik dalam hal, kapasitas dan view yang ditawarkan sesuai dengan standar harga, hal ini akan membuat customer merasa puas akan informasi yang diberikan.
3. Saluran disdtribusi / tempat (place)

a. Tempat acara yang strategis yang berada di kota denpasar, memudahkan customer untuk mencari lokasi acara, selain berpeluang untuk meminimalisir complain, hal ini juga merupakan sebuah peluang untuk mempromosikan tempat penyelenggaraan pernikahan.

b. Luas parker yang luas, penataan kebun, dan dekorasi yang aman bagi pengunjung baii pengunjung dewasa dan anak anak merupakan nilai tambah yang membuat customer nyaman saat acara berlangsung,

c. Modifikasi design dan penambahan atraksi saat acara seperti dance, games, live music yang mengundang pengunjung untuk ikut serta dalam bernyanyi dan atraksi lainnya memberi kesan menyenangkan bagi pengantin dan undangan karena berhasil membuat suasana acara menjadi meriah.

4. Promosi (promotion)

Secara umum bentuk bentuk promosi memiliki fungsi yang relatif sama, namun bentuk bentuk tersebut terlihat berbeda berdasarkan tujuan khususnya yang disebut dengan bauran promosi, antara lain:

a. Personal selling (penjualan pribadi)

Meningkatkan kualitas pelayanan karyawan dengan memberikan pelatiha dan evaluasi yang diadakan oleh pimpinan masing masing section setiap bulannya akan 
meningkatkan kinerja dan secara tidak langsung akan meningkatkan penjualan.

b. Mass selling (penjualan massal)

Dalam hal ini menyampaikan dan berbagi informasi ke halayak ramai menggunakan media komunikasi seperti periklanan dan publisitas dirasa sangat penting. My Wedding

Organizer disarankan untuk dapat berbagi informasi tentang paket, produk yang dimiliki melalui berbagai media seperti website, facebook, Instagram, brosur, baligo dan media lainnya.

c. Sales promotion (promosi penjualan)

Salah satu promosi dalam dalam penjualan adalah dengan menguikuti berbagai event sebagai media promosi dan menawarkan produk yang dimiliki agar semakin banyak masyarakat yang berkunjung yang tertarik untuk memakai jasa My Wedding Organizer sebagai perencana dan perancang pernikajhan mereka, seperti Denpasar Festival.

d. Public relation (hubungan masyarakat)

Dengan memberikan penawaran harga khusus (discount) pada saat menjelang hari besar seperti natal, tahun baru, nyepi dan hari besar lainnya dapat menambah daya Tarik konsumen untuk memakai jasa My Wedding Organizer.

e. Direct marketing (pemasaran langsung)
Sistem pemasaran ini

sebaiknya ditujukan kepada konsumen agar tujuan pesan yang ingin disampaikan dengan baik oleh customer.

5. Orang (people)

Dalam hal ini, otang yang dimaksud adalah seluruh pelaku yang mempunyai peran dalam penyajian jasa sehingga dapat mempengaruhi persepsi pembeli. Terdapat beberapa elemen dari poin ini yang terdiri dari dua aspek yaitu:

a. service people (melayani orang)

Bagi organisasi penyedia jasa, service people (melayani orang) memegang peranan penting yakni mereka dituntut untuk menyediakan jasa hingga menjual jasa tersebut. Pelayanan yang cepat, ramah, teliti dan baik akan menciptakan rasa puas kesetiaan pelangganggan terhadap produk yang ditawarkan.

b. customer (pelanggan)

Customer (pelanggan) juga memiliki andil besar dalam mempengaruhi hubungan yang ada diantara pelanggan. Persepsi yang diberikan pelanggan dapat mempengaruhi pelanggan lainnya yang berkaitan dengan jasa yang pernah dirasakan ketika mendapatkan pelayanan perusahaan. Sebuah keberhasilah dari jasa berkaitan erat dengan seleksi, dan manajemen SDM yang diberikan.

Hal lain yang tidak kalah penting untuk diberikan perhatian dalam operasi jasa yakni bagaimana 
pola dan proses manajemen yang digunakan organisasi agar berlangsung lebih efektif. Pimpinan hendaknya mengupayakan pemerdayaan SDM melalui 4 hal, yakni:

a. Pengekrutan karyawan yang tepat yang sesuai dengan kebutuhan.

b. Memberikan pendidikan dan pelatihan yang memadai

c. Melakukan standarisasi kerja

d. Mengevaluasi kinerja setiap karyawan.

6. Sarana Fisik (physical means) Sarana fisik ini mencakup seluruh aspek fasilitas fisik organisasi. Elemen elemen dari fasilitas fisik organisasi mempengaruhi konsumen melalui eksterior yang ditampilakan (rambu rambu, tempat parkir, halaman dan taman) tampilan interior (tata letak, pencahayaan, design, dekorasi dan sound system), maka dari itu adanya perhatian yang intens dalam hal design dan memodifikasi dekorasi menjadi sangat penting.

7. Proses (process)

Dalam melaksanakan proses pemasaran dalam bentuk jasa seperti ini pemasaran eksternal dan internal sangatlah penting untuk diperhatikan, kedua hal ini akan semakin sempurna jika ditambahkan dengan pemasaran interaktif didalamnya. Jika ketiga proses ini dilakukan dengan baik, maka dapat dipastikan hasil yang didapatkan akan jauh lebih sempurna.

\section{SIMPULAN DAN SARAN}

\section{Simpulan}

Berdasarkan hasil penelitian yang telah dilakukan dengan analisis SWOT yang dibuat dalam matriks
SWOT daoat ditarik kesimpulan sebagai berikut:

1. Dari Strategi SO (strength opportunities), yakni Berinovasi menciptakan produk packages baru seperti anniversary packages, Dengan menganalisa trend pasar yang berkembang saat ini untuk penjualan paket pernikahan. Memperbaharui informasi untuk customer dengan memperbaharui website, dan sering mengupload di sosial media dan media cetak. Memanfaatkan lokasi yang strategis dalam mempromosikan paket pernikahan, seperti memanfaatkan Denpasar Festival, Lebih banyak menjalin kerja sama dengan penginapan (hotel, villa, dan sebagainya) agar memperbanyak ballroom untuk penyelenggaraan pernikahan.

2. Dari Strategi ST (strength-threat) yaitu Mengnambah paket pernikahan yang lebih menarik untuk periode tertentu dan mengkombinasikan produk lama dengan paket tambahan seperti menyewakan kamar di salah satu hotel, dan spa tanpa mengubah makna dari paket tersebut; Merehabilitasi lokasi pernikahan seperti dekorasi dan design area agar terlihat jauh lebih fleksibel dan menarik dan tetap mampu bersaing; Tetap menjaga pesaing dengan mempertahankan produk lama di pasar yang baru.

3. Dari strategi WO (weaknesses opportunities) yakni Promosi lebih digencarkan agar lebih dikenal dan mudah dicari oleh calon pasangan yang akan menikah, sehingga dapat memperbanyak wisatawan mancanegara yang ingin mengadakan acara pernikahan di Bali; Tempat yang digunakan 
untuk megadakan acara pernikahan disesuaikan dengan jumlah pengunjung. alangkah lebih bijak dan menarik jika menentukan tempat didekat objek wisata yang sedang booming saat ini dengan mengusung tema garden party; Menentukan dekorasi dan desigen sesuai dengan budget customer; Memperbaiki kualitas pelayanan dalam penyelenggaraan pernikahan agar dapat meminimalisir complain; Menambah SDM saat penyelenggaraan pernikahan agar pekerjaan menjadi lebih mudah dan cepat diselesaikan; Evaluasi kinerja harus dilakukan sesering mungkin agar mencapai kesepahaman dan sama sama berupaya untuk meminimalisir kesalahan yang telah terjadi kembali terjadi pada acara berikutnya.

4. Dari strategi WT (weaknesses threats), yaitu Meningkatkan keamanan dari saat pemesanan, proses, hingga acara berlangsung; Meminimalkan isu terror kepada customer agar mudah terpengaruh dan panik, sehingga tetap memesan paket pernikahan; Memperluas promosi dengan mengkuti pameran saat pegelaran event tahunan seperti Denpasar Festival dan memasang foto acara yang telah berlangsung.

Formulasi strategi pemasaran yang tepat diterapkan melalui penjabaran analisis SWOT diatas yang berdasarkan bauran pemasaran (marketing mix) yaitu 7P diantaranya sebagai berikut:

A. Produk Jasa (product)

1. Menciptakan inovasi baru dalam hal paket pernikahan seperti bekerja sama dengan beberapa hotel untuk bisa membuat paket yang menyertakan honeymoon.

2. Menambah variasi design, dekorasi ruangan dan variasi acara yang lebih mengikuti zaman agar terlihat lebih menarik.

3. Adanya kombinasi paket pernikahan sebagai ajang promosi agar terlihat lebih menarik minat customer.

B. Harga (price)

1. Perlunya penetapkan harga yang sesuai dengan budget namun tetap dapat menyesuaikan dengan program yang diinginkan customer.

2. Membuat paket pernikahan dengan versi baru sesuai dengan perkembangan zaman, dengan harga yang mampu bersaing dengan competitor dalam penjualan produk.

3. Melakukan pencocokan, pembentukan, serta penyesuaian haga dalam mengarahkan customer saat memilih paket pernikahan yang sesuai dengan kebutuhan dan keinginan mereka, baik dalam hal, kapasitaas dan view yang ditawarkan sesuai dengan standar harga, hal ini akan membuat customer merasa puas akan informasi yang diberikan.

C. Saluran disdtribusi / tempat (place)

1. Tempat acara yang strategis yang berada di kota denpasar, memudahkan customer untuk mencari lokasi acara, selain berpeluang untuk meminimalisir complain, hal ini juga merupakan sebuah 


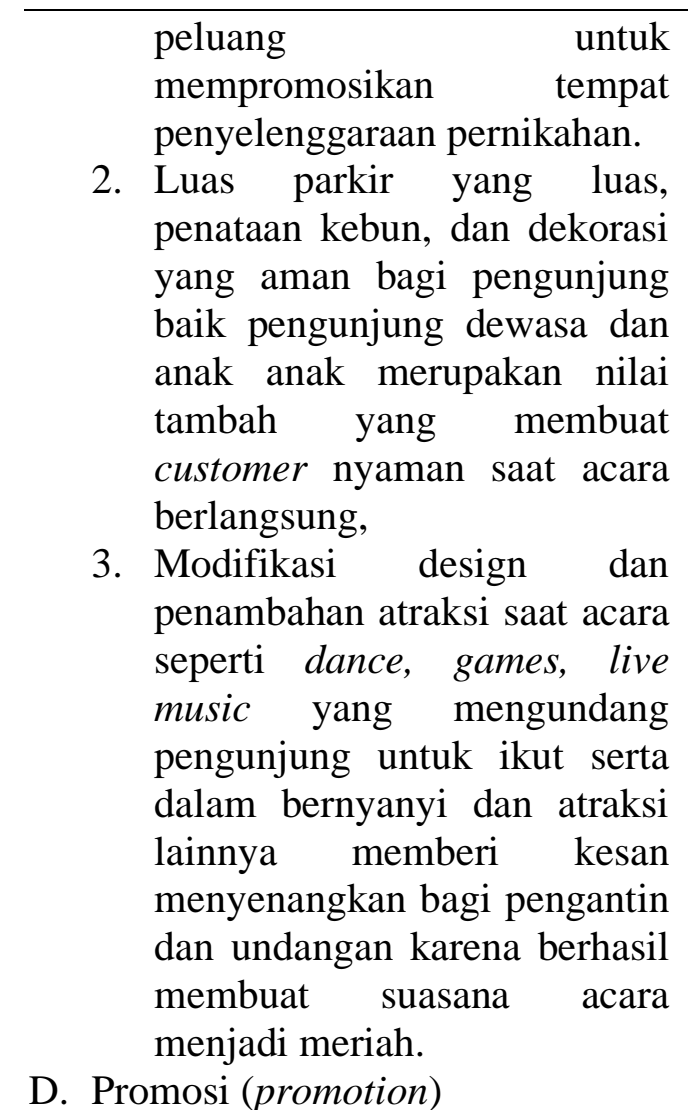

Secara umum bentuk bentuk promosi memiliki fungsi yang relative sama, namun bentuk bentuk tersebut terlihat berbeda berdasarkan tujuan khususnya yang disebut dengan bauran promosi, antara lain: Personal selling (penjualan pribadi); Mass selling (penjualan massal); Sales promotion (promosi penjualan); Public relation (hubungan masyarakat); dan Direct marketing (pemasaran langsung).

E. Orang (people)

Dalam hal ini, otang yang dimaksud adalah seluruh pelaku yang mempunyai peran dalam penyajian jasa sehingga dapat mempengaruhi persepsi pembeli. Terdapat beberapa elemen dari poin ini yang terdiri dari dua aspek yaitu "service people (melayani orang)" dan customer (pelanggan)".
Hal lain yang tidak kalah penting untuk diberikan perhatian dalam operasi jasa yakni bagaimana pola dan proses manajemen yang digunakan organisasi agar berlangsung lebih efektif. Manajemen hendaknya mengupayakan pemerdayaan SDM melalui 4 hal, yakni Pengekrutan karyawan yang tepat yang sesuai dengan kebutuhan; Memberikan pendidikan dan pelatihan yang memadai; Melakukan standarisasi kerja dan Mengevaluasi kinerja setiap karyawan.

F. Sarana Fisik (physical means) Sarana disik ini mencakup seluruh aspek fasilitas fisik organisasi. Elemen elemen dari fasilitas fisik organisasi mempengaruhi konsumen melalui eksterior yang ditampilakan (rambu rambu, tempat parker, halaman dan taman) tampilan interior ( tata letak, pencahayaan, design, dekorasi dan sound system), maka dari itu adanya perhatian yang intens dalam hal design dan memodifikasi dekorasi menjadi sangat penting.

G. Proses (process)

Dalam melaksanakan proses pemasaran dalam bentuk jasa seperti ini pemasaran eksternal dan internal sangatlah penting untuk diperhatikan, kedua hal ini akan semakin sempurna jika ditambahkan dengan pemasaran interaktif didalamnya. Jika ketiga proses ini dilakukan dengan baik, maka dapat dipastikan hasil yang didapatkan akan jauh lebih sempurna.

\section{Saran}

Berdasarkan strategi dari dimpulan diatas, maka dapat diberikan 
beberapa saran yang ditujukan kepada My Wedding Organizer dalam upaya peningkatan penjualan paket pernikahan:

1. Berdasarkan penjabaran hasil penelitian dapat disarankan formulasi strategi yaitu formulasi strategi koorporat, strategi ini dilakukan dengan memperluas jalinan kerjasama dengan penginapan (hotel, villa, dsb) agar memperbanyak ballroom untuk penyelenggaraan pernikahan.

2. Berinovasi menciptakan produk packages baru seperti anniversary packages agar paket yang ditawarkan tidak monotone.

3. Promosi lebih digencarkan agar lebih dikenal dan mudah dicari oleh calon pasangan yang akan menikah, sehingga dapat memperbanyak wisatawan mancanegara yang ingin mengadakan acara pernikahan di Bali; Tempat yang digunakan untuk megadakan acara pernikahan disesuaikan dengan jumlah pengunjung. alangkah lebih bijak dan menarik jika menentukan tempat didekat objek wisata yang sedang booming saat ini dengan mengusung tema garden party; Menentukan dekorasi dan desigen sesuai dengan budget customer; Memperbaiki kualitas pelayanan dalam penyelenggaraan pernikahan.

4. Menambah SDM saat penyelenggaraan pernikahan agar pekerjaan menjadi lebih mudah dan cepat diselesaikan; Evaluasi kinerja harus dilakukan sesering mungkin agar mencapai kesepahaman dan sama sama berupaya untuk meminimalisir kesalahan yang telah terjadi kembali terjadi pada acara berikutnya.

DAFTAR PUSTAKA

Abdurahman. 2011. Tempat terbaik di Dunia untuk Menikah. http://www.uniknya.com

Alma, Buchari. 2000. Manajemen Pemasaran dan Pemasaran Jasa. Bandung: Alfabeta.

Alma, Buchari. 2007. Manajemen Pemasaran dan Pemasaran Jasa, Edisi Revisi.

Assauri, Sofyan. 2002. Manajemen Pemasaran, Dasar, Konsep dan Strategi Raja Grafindo.

Bloom, Paul dan Louise. 2006. Strategi Pemasaran Produk, 18 Langkah Membangun Jaringan Pemasaran Produk Yang Kokoh.

Bogdan, Robert dan Steven Taylor. 1975. Introducing to Qualitative Methods. New York: A Wlley Interscience Publication.

Daniels, Maggie dan Loveless. 2007. Wedding Planning and Management. United Kingdom: Elsevier.

Fathoni, H.A. 2006. Metodologi Penelitian dan Teknik Penyusunan Skripsi. Jakarta: Renaka Cipta.

Goulet dan Ridell. 2005. Fabjob Guide to Become a Wedding Planner. Canada: FabJob. 
Hurriyati, Ratih. 2005. Bauran

Pemasaran dan Loyalitas

Konsumen. Bandung: Alfabet.

Kotler, Philip. 2000. Manajemen Pemasaran, Edisi 2 Millenium, Cetakan Kesepuluh. Jakarta: PT. Prenhalindo.

Kotler, Philip. 2001. Manajemen Pemasaran, Terjemahan Teguh Hendra, Buku 1 Jakarta: Salemba Empat.

Kotler, Philip. 2002. Manajemen Pemasaran Edisi Jakarta Jakarta: Erlangga.

Lupiyoadi, Rambat dan A. Hamdani. 2006. Manajemen Pemasaran Jasa. Jakarta: Salemba Empat.

Mattel, Bruce. 2008. Catering - A Guide to Managing a Succesful Business Operation. New Jersey: The Culinary Institute of America.

Rangkuti, Freddy. 2002. Analisis SWOT Teknik Membedah Kasus Bisnis. Jakarta: PT. Gramedia Pustaka Utama.

Rangkuti, Freddy. 2004. Analisis SWOT Teknik Membedah Kasus Bisnis. Jakarta: PT. Gramedia Pustaka Utama.

Stanton, Nancy Loman. 2007. Catering Management, Third Edition. New Jersey: John Wiley \& Sons, Inc.

Sheri dan Stritof. 2012. History of Marriage.

http://marriage.about.com/o d/historyofmarriage/g/marriag

e.htm.

Soeprianto, John. 1995. Pengantar Bisnis $4^{\text {th }}$ Edition. Yogyakarta: Liberty.

Swastha, Basu. 2000. Azas-azas Marketing. Edisi Ketiga, Cetakan Keempat. Yogyakarta: Liberty.

Tjiptono, Frandy. 2000. Strategi Pemasaran, Edisi Kedua, Cetakan Keempat, Yogyakarta: Andi Publishing.

Tjiptono, Frandy. 2004. Pemasaran Global: Internasionalisasi dan Internetisasi. Yogyakarta: Andi Publishing.

Walgito, Bimo. 1987. Metode Penelitian Masyarakat, Edisi Ketiga. Jakarta: PT. Gramedia Pustaka Utama.

Yazid. 1999. Pemasaran Jasa Konsep dan Implementasi, Edisi Pertama, Cetakan Pertama. Yogyakarta: PT Surya Sarana Utama.

Yoeti, Oka A. 1996. Pengantar Ilmu Pariwisata. Bandung: Angkasa.

Zeithaml, Valerie dan Bitner. 2000. Service Marketing. New Jersey: Graw Hill. 